\title{
ASSESSMENT OF CORNEAL AND CONJUNCTIVAL METAPLASIA BY IMPRESSION CYTOLOGY DURING THE TREATMENT OF CANINE KERATOCONJUNCTIVITIS SICCA
}

\author{
Krzysztof RADZIEJEWSKI $^{1}$, Ireneusz BALICKI ${ }^{2 *}$ and Mateusz SzADKOWSKI ${ }^{2}$ \\ ${ }^{1}$ Veterinary Clinic 'Radvet', Słupsk, Poland; ${ }^{2}$ Department and Clinic of Animal Surgery, \\ Faculty of Veterinary Medicine, University of Life Sciences in Lublin, \\ 13 Akademicka Street, 20-950 Lublin, Poland
}

(Received 27 August 2017; accepted 12 February 2018)

\begin{abstract}
The purpose of this study was to assess the condition of cells in the conjunctiva and corneal epithelium prior to and during cyclosporine- or tacrolimusbased treatment of keratoconjunctivitis sicca (KCS). The study was performed on 40 dogs with KCS. The dogs were divided into two groups of 20 animals each. In Group I, $0.75 \%$ cyclosporine eye drops were administered three times a day, while in Group II $0.02 \%$ tacrolimus eye drops were administered twice daily. Additionally, each group was subdivided into three subgroups based on the results of the Schirmer I tear test (STT I). Evaluation of cellular metaplasia in the cornea and the palpebral and bulbar conjunctiva based on the Nelson-Adams scale was performed by impression cytology using Millipore round filters (Millipore VSWP $01300 \mathrm{DA}$ ) of $25 \mu \mathrm{m}$ pore diameter applied to the studied area. Ophthalmological and cytological examinations were performed prior to the treatment as well as after one and two months of therapy. In both groups, a decrease in Nelson-Adams values was observed, corresponding to the increasing STT values $\left[R_{x y}\right.$ Spearman statistically significant correlation coefficient values between $-0.75(\mathrm{P}<0.001)$ and $-0.45(\mathrm{P}<0.01)]$. The absence of goblet cells was observed in all dogs, regardless of the KCS stage. Goblet cells reappeared following both tacrolimus- and cyclosporine-based treatment in impression cytology specimens classified as 0 in the Nelson-Adams scale. The extent of corneal and conjunctival metaplasia in the course of tacrolimus- and cyclosporine-based treatment of KCS decreases with increasing STT values.
\end{abstract}

Key words: Keratoconjunctivitis sicca, impression cytology, tacrolimus, cyclosporine, dog

Dry eye syndrome (keratoconjunctivitis sicca, KCS) is an ophthalmic disease commonly diagnosed in dogs. It is characterised by inadequate tear production and/or incorrect composition of the lacrimal film, which leads to pathological, inflammatory and degenerative processes in the cornea and conjunctiva. Un-

*Corresponding author; E-mail: balicki.ireneusz@gmail.com; Phone: 0048 (603) 066-376; Fax: 0048 (81) 524-3808 
treated or incorrectly treated KCS can lead to vision impairment or even blindness (Kaswan et al., 1985; Barnett, 1997; Balicki et al., 2008). Most clinical cases entail the immunological form of KCS related to infiltration by mononuclear cells and atrophy of the glandular tissue of lacrimal glands (Kaswan et al., 1984, 1985; Whitley et al., 1991). Early signs of the disease include reddening of the conjunctiva, blepharospasm and the presence of mucoid or mucopurulent exudate in the conjunctival sac. The subsequent stage involves vascular ingrowth, pigmentation and ulceration of the cornea. The results of the Schirmer tear test (STT) facilitate the diagnosis and allow the determination of disease severity. The standard drug used in the treatment of KCS is cyclosporine which is often prepared as oil-solution eye drops (Gilger et al., 1995; Gilger and Allen, 1998; Gelatt, 2007). However, the use of tacrolimus in KCS therapy is currently becoming increasingly popular. It is believed that the effects of the latter are more potent than those of cyclosporine, which allows the medicine to be administered less frequently. Furthermore, the drug is poorly soluble in water but it can be used as an aqueous suspension and thus it causes less irritation and is more easily accepted by animals (Chambers et al., 2002; Berdoulay et al., 2005). In a previous study on the same group of dogs it was found that the application of both tacrolimus $0.02 \%$ aqueous suspension eye drops and cyclosporine $0.75 \%$ oil-solution eye drops resulted in a significant reduction of neovascularisation after the first and second month of treatment. However, in moderate and advanced stages the observed efficacy of tacrolimus was higher (Radziejewski and Balicki, 2016).

The progression of pathological lesions in the conjunctival and corneal region can be evaluated by cytological examination. Cytological specimens can be obtained by invasive and non-invasive methods. The former entail collecting scrapings using special spatulas, brushes or a scalpel (Bauer et al., 1996; Dellman and Eurell, 1998; Cowell et al., 1999; Maggs et al., 2008). Such methods lead to a varying degree of conjunctival damage, which limits their applicability for frequent monitoring of treatment effectiveness and for analysing the effects of medication. The use of invasive methods of collecting cytological specimens is also hindered in cases involving considerable damage to the corneal surface (Thatcher et al., 1977). Among non-invasive methods, cytology of conjunctival sac fluid and impression cytology using cellulose filters can be mentioned (Egbert et al., 1977; Thatcher et al., 1977; Nelson, 1988; Murube and Rivas, 2003; Balicki et al., 2011; Eördögh et al., 2015; Braus et al., 2016). The term 'impression cytology' is used to describe the process of collecting outermost cell layers by applying a cellulose filter. The technique of impression cytology was first described by Egbert et al. in 1977. In human medicine, it is commonly employed in the diagnosis of allergic conjunctivitis, KCS, Chlamydia infection, vitamin A deficiencies, Stevens-Johnson syndrome, mucopolysaccharidoses, and glaucoma (Nelson et al., 1983; Nelson, 1988; Whitley et al., 1991; Nepp et al., 2001; Maggs et al., 2008). 
Impression cytology has also been used for the diagnosis, monitoring and treatment of chronic superficial keratitis in dogs. Results obtained in the course of an 8-month study demonstrated that the observed clinical signs were reflected well by the cytological results (Balicki, 2005).

Balicki et al. (2011) used impression cytology for examining conjunctival and corneal epithelial cells in mixed-breed dogs with KCS. It was observed that conjunctival and corneal epithelial cells of patients with advanced clinical signs were large with irregular, elongated, often curled edges and small pyknotic nuclei. Non-nucleated cells were also present. Regardless of the severity of clinical signs, specimens collected from the bulbar and palpebral conjunctiva contained no goblet cells.

Eördögh et al. (2015) used different filter papers to collect a monolayer of epithelial cells from the feline conjunctiva. The aim of their study was to estimate practicability and determine the most appropriate filter to obtain maximal diagnostic value of impression cytology of the feline eye.

The purpose of this study was to assess the condition of cells in the conjunctival and corneal epithelium prior to and during cyclosporine- or tacrolimusbased treatment of KCS in dogs.

\section{Materials and methods}

This clinical and cytological study was conducted on 40 dogs diagnosed with the immunological form of KCS, which had not been treated for the disease previously. Of the 40 dogs qualified for the study, 21 were male and 19 were female. KCS was diagnosed in dogs aged 1 to 13 years.

The patients underwent detailed ophthalmic examinations using a slit lamp as well as indirect and direct ophthalmoscopy. Schirmer's I tear test (STT I) values were determined with the use of standard strips (Schering-Plough Animal Health). All dog owners were comprehensively interviewed. The dogs were also subjected to thorough clinical examination in order to exclude other diseases. In all dogs, complete blood cell counts were conducted using a URIT-2900 Vet apparatus (Guilin Botest Medical Electronic Co. Ltd.). Serum biochemical profiles were performed to determine the activities of alanine transaminase, alkaline phosphatase and aspartate transaminase, as well as the levels of urea, complete bilirubin, creatinine and glucose using a Rayto RT-1904 VET apparatus (Rayto Electronics Inc.). The dogs showed no clinical signs other than ophthalmological, as confirmed by the haematological and biochemical tests performed. Animals diagnosed with hypothyroidism were excluded from the study.

The dogs were randomly divided into two groups based on the medicine used for the treatment. In Group I 20 dogs received cyclosporine three times a day $(0.75 \%$ oil-solution eye drops), while in Group II tacrolimus $(0.02 \%$ aqueous 
suspension eye drops) was administered twice daily. Additionally, each group was further divided into three subgroups based on the STT results. In both groups, Subgroup I consisted of 6 dogs with STT scores between 0 and 5 $\mathrm{mm} / \mathrm{min}, 7$ dogs with STT scores between 6 and 10 were assigned to Group II, and 7 dogs with STT scores between 11 and 14 to Group III. The STT was conducted using standard strips (Schering-Plough Animal Health).

Where purulent exudate was observed in the conjunctival sac, patients received $0.3 \%$ ofloxacin in the form of Floxal (Dr Mann Pharma) eye drops administered four times daily over a period of two weeks. If the purulent exudate persisted, the patients received a 2 -week treatment with $0.3 \%$ tobramycin drops (Tobrosopt, Polfa S.A.) administered four times daily. In cases of corneal ulceration, dexpanthenol (Corneregel, Dr Mann Pharma) was also administered three times a day.

Cytological examination of the bulbar conjunctiva and corneal epithelium was performed by impression cytology using Millipore round filters (Millipore VSWP 01300 type DA) of $25 \mu \mathrm{m}$ in diameter, which were applied onto the examined surface. Before applying the discs, the conjunctival sacs and corneas were anesthetised with proxymetacaine hydrochloride drops (Alcaine, Alcon). A single disc was used to collect material from the superior and interior temporal quadrants of the cornea and the adjacent bulbar conjunctiva. After collecting the material, the discs were fixed in $96 \%$ alcohol and stained using the PAS method.

Clinical and cytological examinations were conducted prior to treatment as well as after one and two months of therapy.

Evaluation of cytological specimens was performed on the 4-grade Nelson (Nelson, 1988) and Adams (Adams et al., 1988) scale which relies on the morphology of epithelial and goblet cells by classifying them as follows:

Grade 0: Epithelial cells are small, round with good acidophilic staining of cytoplasm, cell nuclei are large, uniform with a nucleus to cytoplasm ratio of 1:1, 1:2; a large number of round and oval goblet cells, staining intensively.

Grade 1: Epithelial cells are slightly smaller and sporadically pleomorphic, cytoplasm staining is less intensive, cell nuclei are smaller, their ratio to cytoplasm is 1:3; goblet cells are slightly less numerous but staining well, the cells are plump, oval, with clearly visible edges.

Grade 2: Larger, pleomorphic epithelial cells with a further reduction of nucleus size down to $1: 4,1: 5$ ratio relative to cytoplasm; cytoplasm staining is not uniform, goblet cells are significantly less numerous, smaller, oval, often with unclear boundaries and reduced staining.

Grade 3: Epithelial cells are large and pleomorphic, often elongated with pyknotic nuclei (sometimes non-nucleated) and very pale cytoplasm, the nucleus to cytoplasm ratio is 1:6 or higher, goblet cells are very scarce or absent, very weakly staining. 
In accordance with the presented scale, conjunctivas classified under grades 0 and 1 are considered healthy, whereas grades 2 and 3 indicate cellular metaplasia.

For the purposes of a comparative analysis of STT scores and cytological examination results of the conjunctiva and cornea obtained prior to treatment and after one and two months of therapy, the Friedman ANOVA statistical test was used for the respective dependent variables. Due to the absence of normal distribution, results were interpreted on the basis of the median, minimum and maximum values rather than mean values and standard deviation.

In order to determine the correlation between STT scores and the condition of the conjunctiva and cornea, Spearman's non-parametric coefficient $\mathrm{R}_{\mathrm{xy}}$ was calculated and its significance was verified by means of the $t$-test.

The statistical analysis was conducted for patient groups treated as a whole, without the division into subgroups.

\section{Results}

After collecting material using impression cytology none of the patients showed signs of blepharospasm as a sign of damage to corneal epithelium and nerve ending exposure. Impression cytology specimens collected from the patients during treatment showed levels of squamous metaplasia consistent with the severity of clinical signs. The detailed results of the study are presented in Tables $1-4$. At the onset of treatment, no goblet cells were present. Corneal and conjunctival epithelial cells gradually rounded up and started to stain more intensively in patients showing treatment progress (Figs 1, 2 and 3). The nucleus to cytoplasm ratio also improved over time. Based on the extent of squamous metaplasia, faster reaction to treatment was observed in cytological specimens obtained from the conjunctiva. Of the 18 conjunctival sac specimens classified as 3 on the Nelson-Adams scale at the beginning of cyclosporine treatment, after two months 12 were classified as grade 1,5 as grade 2 and only 1 as grade 3 . In Group II, of the 22 cytological specimens originally classified as grade 3, after two months of treatment 4 specimens were grade 0,11 were grade 1,5 were grade 2 , and 2 were grade 3 .

Conjunctiva specimens classified as grade 0 on the Nelson-Adams scale contained goblet cells. After the first month of treatment, goblet cells reappeared in 2 Group I conjunctivas and 2 Group II conjunctivas. After the second month, the numbers increased respectively to 12 conjunctivas treated with tacrolimus and 7 treated with cyclosporine.

Impression cytology specimens from the 3 corneas from Subgroup I patients treated with tacrolimus showed no reduction of the Nelson-Adams grade and all from the same specimens remained classified as grade 3 until the end of 
treatment. The same result was obtained for 6 cornea specimens from Subgroup I treated with cyclosporine. In Subgroups of Group I, of 28 corneas classified at the onset of treatment as grade 3, at the end of treatment 6 were classified as grade 3,14 as grade 2, 7 as grade 1 and 1 as grade 0 . In Group II, of 28 corneas classified at the onset of treatment as grade 3, after two months of therapy 6 were classified as grade 3 and 6 as grade 2, 13 were classified as grade 1 and 3 as grade 0 . A statistical analysis of the obtained results revealed a significant decrease in the Nelson-Adams classification grades for conjunctival samples after one and two months of therapy with both tacrolimus and cyclosporine. A statistically significant decrease of Nelson-Adams grading was observed for cytological specimens of the right and left cornea after two months of treatment with cyclosporine and tacrolimus, and for the right cornea after the first month of treatment with tacrolimus (Tables 1-4).

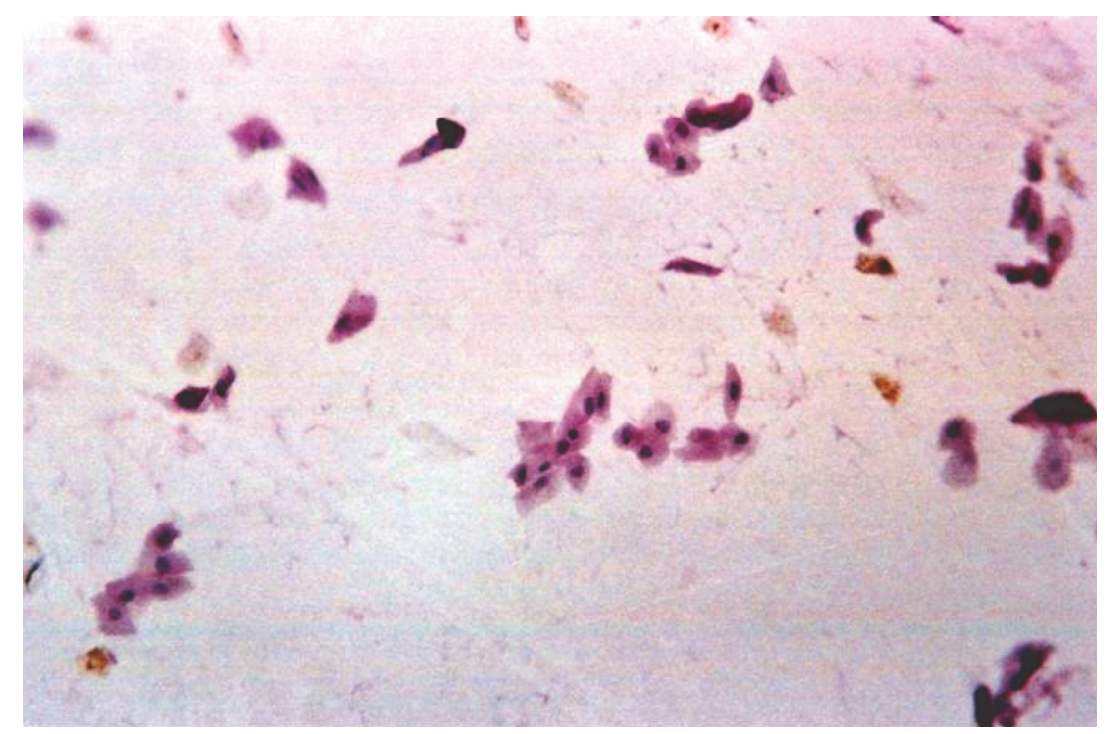

Fig. 1. An impression cytology specimen from the right palpebral conjunctiva of patient no. 2, Subgroup I, Group I after 2 months of treatment. Pleomorphic epithelial cells. Absence of goblet cells - grade 2 on the Nelson-Adams scale. PAS staining, magnification: approx. $\times 120$

The correlation analysis conducted between STT scores and cytological examination results of the conjunctiva and cornea revealed statistically significant correlations (Tables 7 and 8). It was observed that where STT scores increased, the Nelson-Adams scale values decreased (Tables 5 and 6). Such correlations occurred for the left cornea and conjunctiva as well as for the right cornea in Group I after the first month of treatment, as well as for all conjunctivas and corneas after two months of therapy. In Group II, significant correlations were observed after both the first and second month of treatment for the right and left 
conjunctival sac, for both corneas after one month of treatment, and for the left cornea after two months of treatment.

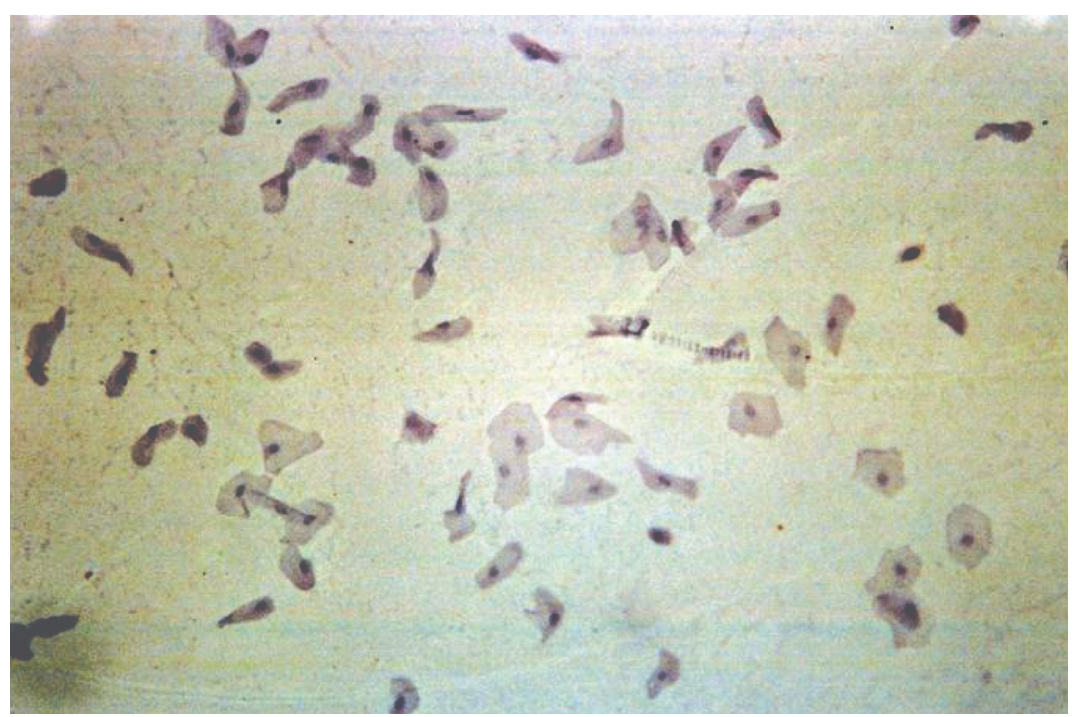

Fig. 2. An impression cytology specimen from the left cornea of patient no. 7, Subgroup II, Group I after one month of treatment. Pleomorphic epithelial cells. Nucleus to cytoplasm ratio 1:4, 1:5 - grade 2 on the Nelson-Adams scale. PAS staining, magnification: approx. $\times 180$

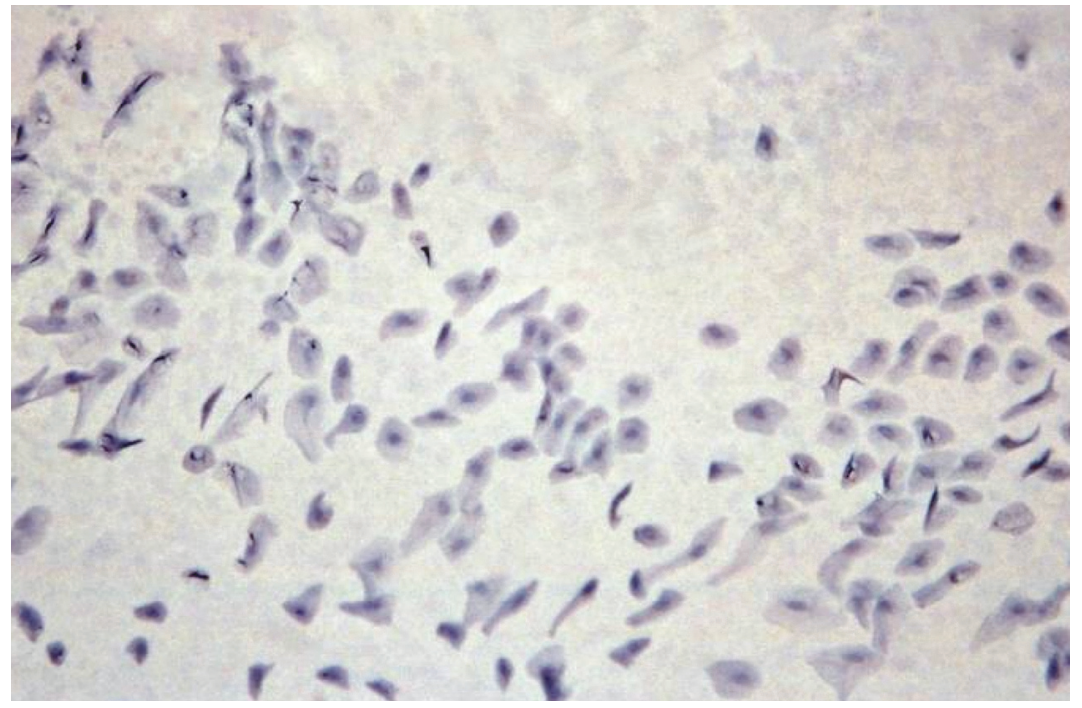

Fig. 3. An impression cytology specimen from the right cornea of patient no. 1, Subgroup I, Group II after 2 months of treatment. Epithelial cells are slightly enlarged. Some cells are normal, some elongated - grade 1 on the Nelson-Adams scale. PAS staining, magnification: approx. $\times 180$ 
Table 1

Assessment of the conjunctiva on the Nelson-Adams scale for Group I patients

\begin{tabular}{|c|c|c|c|c|c|c|}
\hline \multirow{2}{*}{$\begin{array}{l}\text { Patient } \\
\text { no. }\end{array}$} & \multicolumn{2}{|c|}{ Before treatment } & \multicolumn{2}{|c|}{ After 1 month of treatment } & \multicolumn{2}{|c|}{ After 2 months of treatment } \\
\hline & $\begin{array}{c}\text { Right } \\
\text { conjunctiva }\end{array}$ & $\begin{array}{c}\text { Left } \\
\text { conjunctiva }\end{array}$ & $\begin{array}{c}\text { Right } \\
\text { conjunctiva }\end{array}$ & $\begin{array}{c}\text { Left } \\
\text { conjunctiva }\end{array}$ & $\begin{array}{c}\text { Right } \\
\text { conjunctiva }\end{array}$ & $\begin{array}{c}\text { Left } \\
\text { conjunctiva }\end{array}$ \\
\hline & \multicolumn{6}{|c|}{ Subgroup I } \\
\hline 1 & 3 & 3 & 2 & 3 & 2 & 3 \\
\hline 2 & 3 & 3 & 2 & 2 & 2 & 2 \\
\hline 3 & 3 & 3 & 1 & 2 & 1 & 1 \\
\hline 4 & 3 & 3 & 2 & 2 & 2 & 2 \\
\hline 5 & - & 3 & - & 2 & - & 1 \\
\hline \multirow[t]{2}{*}{6} & 3 & 3 & 2 & 1 & 1 & 1 \\
\hline & \multicolumn{6}{|c|}{ Subgroup II } \\
\hline 1 & 2 & 3 & 1 & 1 & 1 & 1 \\
\hline 2 & 2 & 1 & 1 & 1 & 1 & 1 \\
\hline 3 & 3 & 3 & 1 & 2 & 1 & 1 \\
\hline 4 & 2 & 3 & 1 & 2 & 1 & 1 \\
\hline 5 & 1 & 2 & 1 & 1 & 0 & 1 \\
\hline 6 & 1 & 2 & 0 & 2 & 0 & 1 \\
\hline \multirow[t]{2}{*}{7} & 3 & 3 & 2 & 2 & 1 & 1 \\
\hline & \multicolumn{6}{|c|}{ Subgroup III } \\
\hline 1 & 2 & 2 & 1 & 1 & 1 & 1 \\
\hline 2 & 2 & 2 & 2 & 2 & 2 & 2 \\
\hline 3 & 1 & 1 & 1 & 0 & 0 & 0 \\
\hline 4 & 1 & 1 & 1 & 1 & 0 & 0 \\
\hline 5 & 2 & 2 & 1 & 1 & 1 & 0 \\
\hline 6 & - & 2 & - & 1 & - & 1 \\
\hline 7 & 2 & 3 & 2 & 2 & 1 & 1 \\
\hline
\end{tabular}

-: cytological examination was not performed because of unilateral KCS

\section{Discussion}

This study demonstrated that the severity of the clinical signs of KCS is closely reflected by the cytological results. In the impression cytology specimens obtained from patients with advanced clinical signs, extensive metaplasia of conjunctival and corneal epithelial cells was observed - classified as grade 3 on the Nelson-Adams scale. As STT scores increased and the severity of clinical signs decreased, less extensive changes were observed in the cytology specimens of the conjunctival and corneal epithelium. Similar results were reported by other authors who employed impression cytology for monitoring KCS in humans (Marek and Podhorska, 1995). Significant squamous metaplasia was also observed 
when using impression cytology for the assessment of conjunctival and corneal epithelial cells in cases of KCS in mixed-breed dogs. Similar lesions were present in both the cornea and the conjunctiva (Balicki et al., 2011).

Table 2

Assessment of the conjunctiva on the Nelson-Adams scale for Group II patients

\begin{tabular}{|c|c|c|c|c|c|c|}
\hline \multirow{2}{*}{$\begin{array}{l}\text { Patient } \\
\text { no. }\end{array}$} & \multicolumn{2}{|c|}{ Before treatment } & \multicolumn{2}{|c|}{ After 1 month of treatment } & \multicolumn{2}{|c|}{ After 2 months of treatment } \\
\hline & $\begin{array}{c}\text { Right } \\
\text { conjunctiva }\end{array}$ & $\begin{array}{c}\text { Left } \\
\text { conjunctiva }\end{array}$ & $\begin{array}{l}\text { Right } \\
\text { conjunctiva }\end{array}$ & $\begin{array}{c}\text { Left } \\
\text { conjunctiva }\end{array}$ & $\begin{array}{c}\text { Right } \\
\text { conjunctiva }\end{array}$ & $\begin{array}{c}\text { Left } \\
\text { conjunctiva }\end{array}$ \\
\hline & \multicolumn{6}{|c|}{ Subgroup I } \\
\hline 1 & 3 & 3 & 1 & 1 & 1 & 0 \\
\hline 2 & 3 & 3 & 2 & 1 & 1 & 1 \\
\hline 3 & 3 & 3 & 2 & 2 & 2 & 2 \\
\hline 4 & 3 & 3 & 3 & 3 & 3 & 3 \\
\hline 5 & 3 & - & 2 & - & 2 & - \\
\hline \multirow[t]{2}{*}{6} & 3 & 3 & 3 & 3 & 2 & 2 \\
\hline & \multicolumn{6}{|c|}{ Subgroup II } \\
\hline 1 & 3 & 2 & 1 & 0 & 0 & 0 \\
\hline 2 & 2 & - & 1 & - & 1 & - \\
\hline 3 & 3 & 3 & 1 & 1 & 1 & 1 \\
\hline 4 & 3 & 3 & 1 & 2 & 1 & 1 \\
\hline 5 & 2 & 2 & 1 & 1 & 1 & 1 \\
\hline 6 & 3 & 3 & 2 & 2 & 1 & 1 \\
\hline \multirow[t]{2}{*}{7} & 3 & 2 & 1 & 1 & 0 & 0 \\
\hline & \multicolumn{6}{|c|}{ Subgroup III } \\
\hline 1 & 3 & 2 & 1 & 2 & 1 & 0 \\
\hline 2 & 3 & - & 1 & - & 1 & - \\
\hline 3 & 1 & 2 & 1 & 1 & 0 & 0 \\
\hline 4 & 1 & 2 & 0 & 1 & 0 & 0 \\
\hline 5 & 1 & 1 & 1 & 1 & 1 & 1 \\
\hline 6 & 2 & 2 & 1 & 2 & 1 & 1 \\
\hline 7 & 3 & 2 & 1 & 1 & 0 & 0 \\
\hline
\end{tabular}

-: cytological examination was not performed because of unilateral KCS

In their study on humans suffering from KCS, Reddy et al. (1991) reported a significant decrease in the number, or a complete absence, of goblet cells in certain advanced cases. When monitoring diseases causing exfoliation of the corneal epithelium, Singh et al. (1997) observed scarceness of goblet cells and in many cases complete absence of the same. Other studies also reported absence of goblet cells in KCS patients. These cells reappeared only after long-term treatment with sodium hyaluronate in so-called artificial tears (Aragona et al., 2002). It is believed that in dogs suffering from lacrimal film production disorders, re- 
duction of goblet cell counts or their complete disappearance can be common (Moore and Collier, 1990; Balicki et al., 2011). A study by Balicki et al. (2008, 2011) conducted on mixed-breed dogs revealed reduced counts or complete absence of goblet cells at every stage of KCS prior to treatment, regardless of the severity of signs. As a result of treatment, an increase in the number of goblet cells, or their reappearance, was observed in impression cytology specimens already in the first month of therapy. This increase in goblet cell counts correlated with the improvement of STT scores (Balicki et al., 2011). Furthermore, analyses from a previous study revealed that the improvement of STT scores decreased the severity of clinical signs such as vascular ingrowth and corneal pigmentation in those patients (Radziejewski and Balicki, 2016).

Table 3

Assessment of the cornea on the Nelson-Adams scale for Group I patients

\begin{tabular}{|c|c|c|c|c|c|c|}
\hline \multirow{2}{*}{$\begin{array}{l}\text { Patient } \\
\text { no. }\end{array}$} & \multicolumn{2}{|c|}{ Before treatment } & \multicolumn{2}{|c|}{ After 1 month of treatment } & \multicolumn{2}{|c|}{ After 2 months of treatment } \\
\hline & $\begin{array}{c}\text { Right } \\
\text { conjunctiva }\end{array}$ & $\begin{array}{c}\text { Left } \\
\text { conjunctiva }\end{array}$ & $\begin{array}{c}\text { Right } \\
\text { conjunctiva }\end{array}$ & $\begin{array}{c}\text { Left } \\
\text { conjunctiva }\end{array}$ & $\begin{array}{c}\text { Right } \\
\text { conjunctiva }\end{array}$ & $\begin{array}{c}\text { Left } \\
\text { conjunctiva }\end{array}$ \\
\hline & \multicolumn{6}{|c|}{ Subgroup I } \\
\hline 1 & 3 & 3 & 3 & 3 & 3 & 3 \\
\hline 2 & 3 & 3 & 3 & 3 & 3 & 3 \\
\hline 3 & 3 & 3 & 3 & 3 & 1 & 2 \\
\hline 4 & 3 & 3 & 3 & 3 & 3 & 3 \\
\hline 5 & - & 3 & - & 3 & - & 2 \\
\hline \multirow[t]{2}{*}{6} & 3 & 3 & 2 & 2 & 1 & 1 \\
\hline & \multicolumn{6}{|c|}{ Subgroup II } \\
\hline 1 & 3 & 3 & 1 & 1 & 1 & 1 \\
\hline 2 & 3 & 2 & 2 & 2 & 2 & 2 \\
\hline 3 & 3 & 3 & 3 & 3 & 2 & 2 \\
\hline 4 & 3 & 3 & 3 & 3 & 2 & 2 \\
\hline 5 & 3 & 3 & 2 & 3 & 1 & 2 \\
\hline 6 & 2 & 3 & 2 & 2 & 2 & 2 \\
\hline \multirow[t]{2}{*}{7} & 3 & 3 & 2 & 2 & 2 & 1 \\
\hline & \multicolumn{6}{|c|}{ Subgroup III } \\
\hline 1 & 3 & 3 & 3 & 3 & 2 & 2 \\
\hline 2 & 3 & 2 & 2 & 2 & 2 & 2 \\
\hline 3 & 2 & 2 & 1 & 1 & 0 & 0 \\
\hline 4 & 1 & 1 & 1 & 0 & 0 & 0 \\
\hline 5 & 2 & 2 & 1 & 1 & 1 & 1 \\
\hline 6 & - & 2 & - & 1 & - & 1 \\
\hline 7 & 3 & 3 & 1 & 3 & 0 & 2 \\
\hline
\end{tabular}

-: cytological examination was not performed because of unilateral KCS 
Table 4

Assessment of the cornea on the Nelson-Adams scale for Group II patients

\begin{tabular}{|c|c|c|c|c|c|c|}
\hline \multirow{2}{*}{$\begin{array}{l}\text { Patient } \\
\text { no. }\end{array}$} & \multicolumn{2}{|c|}{ Before treatment } & \multicolumn{2}{|c|}{ After 1 month of treatment } & \multicolumn{2}{|c|}{ After 2 months of treatment } \\
\hline & $\begin{array}{l}\text { Right } \\
\text { conjunctiva }\end{array}$ & $\begin{array}{c}\text { Left } \\
\text { conjunctiva }\end{array}$ & $\begin{array}{l}\text { Right } \\
\text { conjunctiva }\end{array}$ & $\begin{array}{c}\text { Left } \\
\text { conjunctiva }\end{array}$ & $\begin{array}{l}\text { Right } \\
\text { conjunctiva }\end{array}$ & $\begin{array}{c}\text { Left } \\
\text { conjunctiva }\end{array}$ \\
\hline & \multicolumn{6}{|c|}{ Subgroup I } \\
\hline 1 & 3 & 3 & 2 & 3 & 1 & 2 \\
\hline 2 & 3 & 3 & 2 & 2 & 1 & 1 \\
\hline 3 & 3 & 3 & 3 & 3 & 3 & 3 \\
\hline 4 & 3 & 3 & 3 & 3 & 3 & 3 \\
\hline 5 & 3 & - & 2 & - & 1 & - \\
\hline \multirow[t]{2}{*}{6} & 3 & 3 & 3 & 3 & 3 & 3 \\
\hline & \multicolumn{6}{|c|}{ Subgroup II } \\
\hline 1 & 3 & 3 & 2 & 2 & 1 & 1 \\
\hline 2 & 3 & - & 2 & - & 1 & - \\
\hline 3 & 3 & 3 & 3 & 2 & 2 & 2 \\
\hline 4 & 3 & 3 & 2 & 2 & 1 & 1 \\
\hline 5 & 2 & 2 & 1 & 2 & 1 & 1 \\
\hline 6 & 3 & 3 & 3 & 3 & 1 & 2 \\
\hline \multirow[t]{2}{*}{7} & 3 & 2 & 2 & 2 & 1 & 1 \\
\hline & \multicolumn{6}{|c|}{ Subgroup III } \\
\hline 1 & 3 & 2 & 1 & 1 & 0 & 0 \\
\hline 2 & 3 & - & 2 & - & 1 & - \\
\hline 3 & 2 & 3 & 1 & 1 & 1 & 0 \\
\hline 4 & 1 & 2 & 1 & 1 & 0 & 1 \\
\hline 5 & 2 & 2 & 2 & 1 & 1 & 1 \\
\hline 6 & 3 & 3 & 2 & 2 & 2 & 2 \\
\hline 7 & 3 & 3 & 1 & 1 & 1 & 0 \\
\hline
\end{tabular}

-: cytological examination was not performed because of unilateral KCS

In a study conducted by Oziębło-Kubczyk et al. (2006), goblet cell counts in KCS cases depended on the severity of lesions, but even in the most advanced cases individual goblet cells were present. Indeed, in certain moderately advanced cases of squamous metaplasia, the reported counts were considerably high. Adams et al. (1988) and Tseng et al. (1995) concluded that the absence or reduced presence of goblet cells in the conjunctiva is an early sign of squamous metaplasia. This observation was confirmed in our own research, where even the early stages of squamous metaplasia entailed a complete absence of goblet cells. It is generally believed that reduced production of the aqueous fraction in KCS cases is compensated by the increased production of mucin by goblet cells (Matsumoto et al., 1996). The same was not confirmed in our study as the absence of goblet cells was observed prior to treatment in all dogs, regardless of the 
KCS stage, which may be evidence of a mucin deficit (Balicki et al., 2011). This results in the destabilisation of the lacrimal films, reduced moisturisation, and increased risk of bacterial infection (Sebbag et al., 2016). Impression cytology cornea specimens which revealed the presence of goblet cells were classified as grade 0 on the Nelson-Adams scale. After two months of tacrolimus treatment, goblet cells were present in 12 conjunctivas, as compared to 7 conjunctivas in the group treated with cyclosporine. Furthermore, the Schirmer test scores improved and the severity of clinical signs decreased in those patients. This could indicate a higher effectiveness of tacrolimus treatment in certain stages of KCS as compared to cyclosporine.

\section{Table 5}

Schirmer tear test (STT) scores and results of cytological examination of the conjunctiva and cornea on the Nelson-Adams scale for Group I

\begin{tabular}{|c|c|c|c|c|c|c|}
\hline & \multicolumn{2}{|c|}{ Before treatment } & \multicolumn{2}{|c|}{$\begin{array}{l}\text { After } 1 \text { month of } \\
\text { treatment }\end{array}$} & \multicolumn{2}{|c|}{$\begin{array}{l}\text { After } 2 \text { months of } \\
\text { treatment }\end{array}$} \\
\hline & $\begin{array}{l}\text { Right } \\
\text { eye }\end{array}$ & $\begin{array}{l}\text { Left } \\
\text { eye }\end{array}$ & $\begin{array}{l}\text { Right } \\
\text { eye }\end{array}$ & $\begin{array}{l}\text { Left } \\
\text { eye }\end{array}$ & $\begin{array}{l}\text { Right } \\
\text { eye }\end{array}$ & $\begin{array}{l}\text { Left } \\
\text { eye }\end{array}$ \\
\hline $\begin{array}{l}\text { STT }(\operatorname{mm}) \\
\operatorname{Me}(\min -\max )\end{array}$ & $\begin{array}{c}8.5 \\
(2-14)\end{array}$ & $\begin{array}{c}9.0 \\
(0-13)\end{array}$ & $\begin{array}{c}11.0 \\
(4-17)\end{array}$ & $\begin{array}{c}11.0 \\
(0-17)\end{array}$ & $\begin{array}{l}13.0^{*} \\
(2-19)\end{array}$ & $\begin{array}{l}12.5^{*} \\
(0-20)\end{array}$ \\
\hline $\begin{array}{l}\text { Cytology of the conjunctiva } \\
\text { Me (min-max) }\end{array}$ & $\begin{array}{c}2.0 \\
(1-3)\end{array}$ & $\begin{array}{c}3.0 \\
(1-3)\end{array}$ & $\begin{array}{l}1.0^{* * *} \\
(0-2)\end{array}$ & $\begin{array}{l}2.0^{* * *} \\
(0-3)\end{array}$ & $\begin{array}{l}1.0^{* * *} \\
(0-2)\end{array}$ & $\begin{array}{l}1.0^{* * *} \\
(0-3)\end{array}$ \\
\hline $\begin{array}{l}\text { Cytology of the cornea } \\
\text { Me (min-max) }\end{array}$ & $\begin{array}{c}3.0 \\
(1-3)\end{array}$ & $\begin{array}{c}3.0 \\
(1-3)\end{array}$ & $\begin{array}{c}2.0 \\
(1-3)\end{array}$ & $\begin{array}{c}2.5 \\
(0-3)\end{array}$ & $\begin{array}{l}2.0^{* * *} \\
(0-3)\end{array}$ & $\begin{array}{l}2.0^{* *} \\
(0-3)\end{array}$ \\
\hline
\end{tabular}

Me: median; min-max: minimum and maximum values. Statistically significant differences: ${ }^{*} \mathrm{P}<$ $0.05 ;{ }^{* *} \mathrm{P}<0.01:{ }^{* * *} \mathrm{P}<0.001$

\section{Table 6}

Schirmer tear test (STT) scores and results of cytological examination of the conjunctiva and cornea on the Nelson-Adams scale for Group II

\begin{tabular}{|c|c|c|c|c|c|c|}
\hline & \multicolumn{2}{|c|}{ Before treatment } & \multicolumn{2}{|c|}{$\begin{array}{l}\text { After } 1 \text { month of } \\
\text { treatment }\end{array}$} & \multicolumn{2}{|c|}{$\begin{array}{l}\text { After } 2 \text { months of } \\
\text { treatment }\end{array}$} \\
\hline & $\begin{array}{l}\text { Right } \\
\text { eye }\end{array}$ & $\begin{array}{l}\text { Left } \\
\text { eye }\end{array}$ & $\begin{array}{l}\text { Right } \\
\text { eye }\end{array}$ & $\begin{array}{l}\text { Left } \\
\text { eye }\end{array}$ & $\begin{array}{l}\text { Right } \\
\text { eye }\end{array}$ & $\begin{array}{l}\text { Left } \\
\text { eye }\end{array}$ \\
\hline $\begin{array}{l}\mathrm{STT}(\mathrm{mm}) \\
\operatorname{Me}(\min -\max )\end{array}$ & $\begin{array}{c}8.0 \\
(0-14)\end{array}$ & $\begin{array}{c}8.0 \\
(2-14)\end{array}$ & $\begin{array}{l}12.5^{* *} \\
(1-18)\end{array}$ & $\begin{array}{l}12.0^{* *} \\
(1-17)\end{array}$ & $\begin{array}{l}13.0^{* *} \\
(1-19)\end{array}$ & $\begin{array}{l}14.0^{* *} \\
(0-19)\end{array}$ \\
\hline $\begin{array}{l}\text { Cytology of the conjunctiva } \\
\operatorname{Me}(\min -\max )\end{array}$ & $\begin{array}{c}3.0 \\
(1-3)\end{array}$ & $\begin{array}{c}2.0 \\
(1-3)\end{array}$ & $\begin{array}{l}1.0^{* * *} \\
(0-3)\end{array}$ & $\begin{array}{l}1.0^{* * *} \\
(0-3)\end{array}$ & $\begin{array}{l}1.0^{* * *} \\
(0-3)\end{array}$ & $\begin{array}{l}1.0^{* * *} \\
(0-3)\end{array}$ \\
\hline $\begin{array}{l}\text { Cytology of the cornea } \\
\mathrm{Me}(\min -\max )\end{array}$ & $\begin{array}{c}3.0 \\
(1-3)\end{array}$ & $\begin{array}{c}3.0 \\
(2-3)\end{array}$ & $\begin{array}{l}2.0^{* * *} \\
(1-3)\end{array}$ & $\begin{array}{c}2.0 \\
(1-3)\end{array}$ & $\begin{array}{l}1.0^{* * *} \\
(0-3)\end{array}$ & $\begin{array}{l}1.0^{* * *} \\
(0-3)\end{array}$ \\
\hline
\end{tabular}

Me: median; min-max: minimum and maximum values. Statistically significant differences: ${ }^{* *} \mathrm{P}<$ $0.01:^{* * *} \mathrm{P}<0.001$ 
Table 7

Correlations between Schirmer tear test (STT) scores and cornea and conjunctiva assessments on the Nelson-Adams scale in Group I

\begin{tabular}{|c|c|c|c|c|}
\hline \multirow{2}{*}{ Coefficient of correlation } & \multicolumn{2}{|c|}{$\begin{array}{l}\text { After } 1 \text { month of } \\
\text { treatment }\end{array}$} & \multicolumn{2}{|c|}{$\begin{array}{l}\text { After } 2 \text { months of } \\
\text { treatment }\end{array}$} \\
\hline & $\begin{array}{l}\text { Right } \\
\text { eye }\end{array}$ & $\begin{array}{l}\text { Left } \\
\text { eye }\end{array}$ & $\begin{array}{l}\text { Right } \\
\text { eye }\end{array}$ & $\begin{array}{l}\text { Left } \\
\text { eye }\end{array}$ \\
\hline $\begin{array}{l}\mathrm{R}_{\mathrm{xy}}-\text { Spearman's coefficient of correlation } \\
\text { between STT and conjunctiva assessment on } \\
\text { the Nelson-Adams scale }\end{array}$ & -0.36 & $-0.54^{* * *}$ & $-0.55^{* * *}$ & $-0.45^{* *}$ \\
\hline $\begin{array}{l}\mathrm{R}_{\mathrm{xy}}-\text { Spearman's coefficient of correlation } \\
\text { between STT and cornea assessment on the } \\
\text { Nelson-Adams scale }\end{array}$ & $-0.74^{* * *}$ & $-0.50^{* *}$ & $-0.65^{* * *}$ & $-0.56^{* * *}$ \\
\hline
\end{tabular}

" a significant correlation between the variables is present: with increasing STT scores the NelsonAdams values decrease. Statistically significant differences: ${ }^{* *} \mathrm{P}<0.01 ;{ }^{* * *} \mathrm{P}<0.001$

\section{Table 8}

Correlations between STT scores and cornea and conjunctiva assessments on the Nelson-Adams scale in Group II

\begin{tabular}{|c|c|c|c|c|}
\hline \multirow{2}{*}{ Coefficient of correlation } & \multicolumn{2}{|c|}{$\begin{array}{l}\text { After } 1 \text { month of } \\
\text { treatment }\end{array}$} & \multicolumn{2}{|c|}{$\begin{array}{l}\text { After } 2 \text { months of } \\
\text { treatment }\end{array}$} \\
\hline & $\begin{array}{l}\text { Right } \\
\text { eye }\end{array}$ & $\begin{array}{l}\text { Left } \\
\text { eye }\end{array}$ & $\begin{array}{l}\text { Right } \\
\text { eye }\end{array}$ & $\begin{array}{l}\text { Left } \\
\text { eye }\end{array}$ \\
\hline $\begin{array}{l}\mathrm{R}_{\mathrm{xy}}-\text { Spearman's coefficient of correlation } \\
\text { between STT and conjunctiva assessment on } \\
\text { the Nelson-Adams scale }\end{array}$ & $-0.74^{* * *}$ & $-0.60^{* * *}$ & $-0.75^{* * *}$ & $-0.71^{* * *}$ \\
\hline $\begin{array}{l}\mathrm{R}_{\mathrm{xy}}-\text { Spearman's coefficient of correlation } \\
\text { between STT and cornea assessment on the } \\
\text { Nelson-Adams scale }\end{array}$ & $-0.58^{* * *}$ & $-0.70^{* * *}$ & -0.42 & $-0.69^{* * *}$ \\
\hline
\end{tabular}

* a significant correlation between the variables is present: with increasing STT scores the NelsonAdams values decrease. Statistically significant differences: ${ }^{* *} \mathrm{P}<0.01 ;{ }^{* * * *} \mathrm{P}<0.001$

As observed by Nelson et al. (1983) and Nelson (1984, 1988), impression cytology specimens usually allow the collection of material from 1-3 top layers of cells. Furthermore, impression cytology allows the collection of material from larger areas, thus providing a more representative specimen. Studies conducted on KCS patients demonstrated that impression cytology is on a par with other methods of collecting cytology specimens (Marek and Podhorska, 1995). Our own research has proved that impression cytology as a non-invasive method is suitable for monitoring the treatment of KCS in dogs. 


\section{References}

Adams, G. G. W., Dilly, P. N. and Kirkness, C. M. (1988): Monitoring ocular disease by impression cytology. Eye 2, 506-516.

Aragona, P., Papa, V., Micali, A., Santocono, M. and Milazzo, G. (2002): Long term treatment with sodium hyaluronate-containing artificial tears reduces ocular surface damage in patients with dry eye. Br. J. Ophthalmol. 86, 181-184.

Balicki, I. (2005): Research on diagnostic and treatment of chronic superficial keratitis in dogs. Postdoctoral Dissertation. WAR Lublin 204, 14-34.

Balicki, I., Radziejewski, K. and Bielecki, W. (2011): Evaluation of corneal and conjunctival epithelium with the use of impression cytology in mixed-breed dogs diagnosed with keratoconjunctivitis sicca. Bull. Vet. Inst. Puławy 55, 493-499.

Balicki, I., Radziejewski, K. and Silmanowicz, P. (2008): Studies on keratoconjunctivitis sicca incidence in crossbreed dogs. Pol. J. Vet. Sci. 11, 353-358.

Barnett, K. (1997): Diagnosis and treatment of keratoconjunctivitis sicca in the dog. Vet. Rec. 120, 340-345.

Bauer, G. A., Spiess, B. M. and Lutz, H. (1996): Exfoliative cytology of conjunctiva and cornea in domestic animals: a comparison of four collecting techniques. Vet. Comp. Ophthalmol. 6, 181-186.

Berdoulay, A., English, R. and Nadelstein, B. (2005): Effect of topical $0.02 \%$ tacrolimus aqueous on tear production in dogs with keratoconjunctivitis sicca. Vet. Ophthalmol. 8, 225-232.

Braus, B. K., Lehenauer, B., Tichy, A., Nell, B. and Schwendenwein, I. (2016): Impression cytology as diagnostic tool in horses with and without ocular surface disease. Equine Vet J. 12, $1-7$.

Chambers, L., Fischer, C., McCalla, T., Parshall, C., Slatter, D. and Yakley, B. (2002): Topical tacrolimus in treatment of canine keratoconjunctivitis sicca: a multicenter preliminary clinical trial. Materials of Scientific Meeting of the American College of Veterinary Ophthalmologists, Denver.

Cowell, R. L., Tyler, R. D. and Meinkoth, J. H. (1990): Diagnostic Cytology and Hematology of the Dog and Cat. Mosby, Philadelphia.

Dellman, H. D. and Eurell, J. A. (1998): Textbook of Veterinary Histology. Williams and Wilkins, London.

Egbert, P. R., Lauber, S. and Maurice, D. M. (1977): A simple conjunctival biopsy. Am. J. Ophthalmol. 84, 798-801.

Eördögh, R., Schwendenwein, I., Tichy, A. and Nell, B. (2015): Impression cytology: a novel sampling technique for conjunctival cytology of the feline eye. Vet. Ophthalmol. 18, 276-284.

Gelatt, K. N. (2007): Veterinary Ophthalmology, 4th edition. Blackwell Publishing, Ames, Iowa. pp. 633-671.

Gilger, B. and Allen, J. (1998): Cyclosporine A in veterinary ophthalmology. Vet. Ophthalmol. 1, 181-187.

Gilger, B., Andrews, J., Wilkie, D., Wyman, M. and Lairmore, M. (1995): Cellular immunity in dogs with keratoconjunctivitis sicca before and after treatment with topical $2 \%$ cyclosporine. Vet. Immunol. Immunopathol. 49, 199-208.

Kaswan, R. L., Martin, C. and Chapman, W. L. (1984): Keratoconjunctivitis sicca: histopathologic study of nictitating membrane and lacrimal glands from 28 canine cases. Am. J. Vet. Res. 45, $112-118$.

Kaswan, R. L., Martin, C. and Dawe, D. (1985): Keratoconjunctivitis sicca: immunological evaluation of 62 canine cases. Am. J. Vet. Res. 46, 376-383.

Maggs, D. J., Miller, P. E. and Ofri, R. (2008): Slatter's Fundamentals of Veterinary Ophthalmology, 4th edition. Saunders, St. Louis, pp. 166-171. 
Marek, J. and Podhorska, M. (1995): Evaluation of changes in the cells of conjunctival epithelium in dry eye syndrome by impression cytology. Klinika Oczna 97, 176-181.

Matsumoto, I., Tsubota, K., Satake, Y., Kita, Y., Matsumura, R., Murata, H., Namekawa, T., Nishioka, K., Iwamoto, I., Saitoh, Y. and Sumida, T. (1996): Common T cell receptor clonotype in lacrimal glands and labial salivary glands from patients with Sjögren's syndrome. J. Clin. Invest. 8, 1969-1977.

Moore, C. P. and Collier, L. L. (1990): Ocular surface disease associated with loss of conjunctival goblet cells in dogs. J. Am. Anim. Hosp. Assoc. 26, 458-465.

Murube, J. and Rivas, L. (2003): Impression cytology on conjunctiva and cornea in dry eye patients establishes a correlation between squamous metaplasia and dry eye clinical severity. Eur. J. Ophthalmol. 13, 115-127.

Nelson, J. D. (1984): Conjunctival goblet cell densities in ocular surface disease. Arch. Ophthalmol. 102, 1049-1051.

Nelson, J. D. (1988): Impression cytology. Cornea 7, 71-81.

Nelson, J. D., Havener, V. R. and Cameron, J. D. (1983): Cellulose acetate impressions of the ocular surface. Dry eye states. Arch. Ophthalmol. 101, 1869-1872.

Nepp, J., Schauersberger, J., Schild, G., Jandrasits, K., Haslinger-Akramian, J., Derbolav, A. and Wedrich, A. (2001): The clinical use of viscoelastic artificial tears and sodium chloride in dry-eye syndrome. Biomaterials 22, 3305-3310.

Oziębło-Kupczyk, M., Średzińska-Kita, D., Kita, K. and Mrugacz, M. (2006): Impression cytology in dry eye syndrome in selected rheumatological diseases [in Polish]. Klinika oczna 108, $10-12$.

Radziejewski, K. and Balicki, I. (2016): Comparative clinical evaluation of tacrolimus and cyclosporine eye drops for the treatment of canine keratoconjunctivitis sicca. Acta Vet. Hung. 64, 313-329.

Reddy, M., Reddy, P. R. and Reddy, P. C. (1991): Conjunctival impression cytology in dry eye states. Indian J. Opthalmol. 39, 22-24.

Sebbag, L., Reilly, C. M., Eid, R. and Maggs, D. J. (2016): Goblet cell density and distribution in cats with clinically and histologically normal conjunctiva. Vet. Ophthalmol. 19, Suppl. 1, $38-43$.

Singh, M., Singh, G., Dwevedi, S., Singh, K., Kumar, D., Tiwari, A. and Aggarwal, M. (1997): Conjunctival impression cytology in xerophthalmia among rural children. Indian J. Opthalmol. 45, 25-29.

Thatcher, R. W., Darougar, S. and Jones, B. R. (1977): Conjunctival impression cytology. Arch. Ophthalmol. 95, 678-681.

Tseng, S. C. G., Maumenee, A. E., Stark, W. J., Maumenee, I. H., Jensen, A. D., Green W. R. and Kenyon, K. R. (1995): Topical retinoid treatment for various dry eye disorders. Ophthalmology 92, 717-733.

Whitley, D., McLaughlin, S., Gilger, B. and Lindley, D. (1991): The treatments for keratoconjunctivitis sicca. Vet. Med. 11, 1076-1093. 